\title{
WALT WHITMAN AND THE EPIC TRADITION: POLITICAL AND POETICAL VOICES IN "SONG OF MYSELF"
}

\author{
BiLl HARDwig
}

What is America for?-To commemorate the old myths and the gods? To repeat the Mediterranean here? . . - - No;- (Nä-o-o) but to destroy all these from the purposes of the earth, and to erect a new earth in their place.

-Whitman in the $1850 \mathrm{~s}^{1}$

WaLt Whitman's explicit dismissal of the mythology of the Greek and Roman Empires epitomizes his general suspicion of long-lived traditions - cultural, philosophical, or poetical. Whitman felt that if he were to redefine American notions of poetry and heroism, Leaves of Grass must, in his words, "take no illustrations from the ancients or classics." 2 He believed that poetry needed to be disruptive and revaluative-breaking away from past traditions rather than extending them. Although "Song of Myself" contains several obvious structural and thematic echoes of ancient epic poetry, Whitman employs these conventions in a disruptive manner in order to challenge the mythic authority of the epic tradition. Through his manipulation of epic conventions, Whitman forces a confrontation between "Song of Myself" and the "myths" of the epic tradition in order to question the ideological and political ramifications of ancient poetry and, I will argue, contemporary conservative political rhetoric.

Perhaps the tension between Whitman's use of the themes and structure of epic poetry and his renunciation of the "myth" of classical tradition can be explained, in part, by examining the ancient epics that Whitman undermines in the context of his contemporary political and cultural milieu. Through an analysis of the thematic and formal parallels between epic poetry (Virgil's Aeneid will function illustratively here) and the political rhetoric of the mid-nineteenth century, we are able to understand why Whitman chooses to borrow conventions of epic rhetoric (such as the "high" epic voice, narrator, and catalogues), while rejecting the underlying functions of the genre as a whole. By implementing the rhetoric of the epic poem to elicit superficial comparisons between his poem and the epic genre, Whitman is able to interrogate the more deeply ingrained and implicit aspects of the epic's role in the shaping of cultural ideology. In short, Whitman seeks to expose the rhetorical artifice of epic narration-the ways in which epic poets manufacture consent-and in so doing, create an "anti-epic" that contests the establishment of conservative ideological consensus. ${ }^{3}$ 
One scholar of the epic, Suzanne Wofford, explains that the ideology in epic poetry contains "the entire set of unacknowledged assumptions and invisible interpretive solutions by which people understand and represent to themselves their relation to the world, and, similarly, the unexpressed presuppositions of logical requirements of an ethical or a political system." 4 It is these political and ideological systems, and their "unexpressed presuppositions" within epic poetry, that Whitman contests.

Although there is wide-ranging and proliferating critical commentary about Whitman's engagement with the epic genre, scholars still generally understand "Song of Myself" as a revision or extension of the epic mode. ${ }^{5}$ Most notably, James E. Miller, Jr., has gracefully argued that Whitman revises the epic genre in "Song of Myself" and creates the first American "Lyric-Epic." Miller regards Whitman as "an epic poet who will break all the rules for the epic, but insist on writing an epic anyway" (33). For him, there are several aspects of Whitman's poem that are at odds with his "epic intent," such as his lyric voice and his "indignation with reality" (47). He sees Whitman repeatedly "prodding himself, reminding himself of his epic role" (44).

Traditionally, epic poetry bolsters conservative ideologies by rendering mythic a society's political history, and in so doing, camouflaging its more tyrannical motives. ${ }^{7}$ Epic poets do not purport to represent a particular political and historical faction of society; rather, they claim to relay the self-evident, universal, and destined truths of a nation. For example, in The Aeneid, Virgil declares that the story he tells is destined and already completed, that he merely has been called to sing its song:

Be with me, Muse of all Desire, Erato,

While I call up the kings, the early times,

How matters stood in the old land of Latium

$\cdots$

A greater history opens before my eyes,

A greater task awaits me. (VII, 47-59) ${ }^{8}$

Seduced by the song, Virgil's audience is led to accept his ideological assertions (e.g., the validity of Roman colonization) without examining their contemporary implications or the poet's possible motives. When Virgil claims that the Romans are "incorporating" and "pacifying" weaker nations, the implications of this action can remain subordinate because they are pronounced under the rubric of a fated and justified Roman history. To question Virgil's defense of Roman colonization is to undermine the mythos supporting The Aeneid.

Like the genealogical catalogue in The Book of Genesis, which provides a certainty and historical continuity within the Judeo-Christian tradition, epic catalogues customarily serve to provide historical grounding and a sense of identity for the reader by symbolically connecting the 
past and the present. Through ideas of the organic harmony of the poem's ideology and a "destined" history, epic poetry symbolically connects the reader to the time of the events, making the reader feel invested in the moral and political messages of the poetry (McWilliams, 225). However, it does so while maintaining an "epic distance," which prevents any questioning of the ideological consequences of such a connection. ${ }^{9}$ Although epics are created in specific historical contexts, the poets seek to efface the historical complexities and conflicts of these contexts from their poetry. The "distance" of classical epic poetry functions in a manner similar to the way that ideological systems operate in general: "An ideology," according to Sacvan Bercovitch, "arises out of historical circumstances, and then re-presents these, symbolically and conceptually, as though they were natural, universal, and right." 10

For example, in The Aeneid Virgil creates the impression that he is portraying the distant past of Roman genealogy merely as historical context. However, by having the omniscient gods and nearly infallible heroes of his epic speak of Roman destiny and the inevitability of Roman triumph, he justifies Rome's subsequent imperialism. Because the events are locked in the unchangeable and distant past, they convey immutability and inevitability. Through this rhetorical ploy of creating a sense of historical destiny, Virgil is able to explain contemporary events through their relation to, and connection with, the past; by yoking contemporary actions to historical precedent, he gives modern Rome justification to follow the doctrine outlined in the epic past. In Book VI, Aeneas is in the underworld, listening to the shade of his father. Because he is a member of the underworld, Anchises is able to see the future and he foretells Aeneas's destiny:

Roman, remember by your strength to rule

Earth's peoples - for your arts are to be these:

To pacify, to impose the rule of law,

To spare the conquered, battle down the proud. (VI, 1151-1154)

In this brief prophecy, Anchises not only excuses Roman imperialism, he couches it in the terms of "pacifying" the barbarians; this becomes Aeneas's true "art." In this light, Rome's brutal conquest becomes an act of compassion and assistance. Clearly, Virgil included these details in part as an example of proper beneficent rule; Aeneas is to "spare the conquered." From this perspective, he can be contrasted with Turnus's "lust for steel" and "brute insanity in war" (VII, 634-635). Nonetheless, because this scene takes place in the "historical" past, the sanctity of that past (sanctified in part by the poem's epic distance) allows Virgil to promote without interrogation a specific political ideology of colonialism. 
Even a schematic inspection of how Virgil's ideology informs his poem can reveal how he promulgates a monolithic and prescriptive view of Roman political history. It is important to realize that the ideological rhetoric in Virgil's poem often contains implied premises that can alter or contradict the surface values that the poem claims to exalt. For example, in Book XII, Virgil superficially claims to grant equality to everybody - both the conquerors and the conquered - in the new Latin empire:

Let both nations, both unconquered, both

Subject to equal laws, commit themselves

To an eternal union. . . . (XII, 257-259)

However, Jupiter immediately undermines this equality and covertly establishes an unequivocal hierarchy of status and autonomy:

\section{... Ausonion folk will keep}

Their fathers' language and their way of life,

And, that being so, their name: The Teucrians

Will mingle and be submerged, incorporated. (XII, 1131-1134, emphasis added)

As these lines illustrate, the implicit premise that a hierarchy is desired, if not necessary, lies beneath the stated ideals of nationhood and brotherhood. However, because Jupiter proclaims the incorporation of the colonized people as destined, Virgil and the reader have no cause to question such a policy. In fact, in many cases it is an epic's underlying premises that make the propagation of its ideological system viable.

I am not suggesting that Virgil's Aeneid functions in the same manner as all epics - that there is some universal epic formula. Yet there is much evidence suggesting that The Aeneid stood in the eighteenth- and nineteenth-century American literary imagination as The Epic, against which all other poetry was measured. For example, in his 1702 work, Magnalia Christi Americana, written to preserve New England's deteriorating sense of religious mission, Cotton Mather invoked (and slightly altered) Virgil's opening invocation in The Aeneid: "The reader will doubtless desire to know what it was that "tot volvere casus / Insignes pietate viros, tot adire labores Impulerit." In the 1780s Samuel Low wrote that the Muse of Freedom would inspire his poetry, and added that a "new Virgil [will] grace this western shore." A 1784 commencement speech delivered at the University of Pennsylvania claimed that Americans would soon see a national poetry with "the correct majesty of Virgil." From 1807 to 1809, the Monthly Anthology and Boston Review published six articles on Virgil, in large part to prove that American poets were not capable of creating a "true" epic (cited in McWilliams, 18, 19). As the epigraph at the beginning of this essay illustrates, Whitman knew the 
mythological, Mediterranean epics as a standard commonly invoked to judge lengthy American poems. For Whitman the respect for these epics must be "destroyed."

Perhaps one way of understanding why Whitman so firmly distances himself from the epic tradition is to explore the specific political contingencies during the inception of "Song of Myself." In fact, Whitman's disdain for Virgil's poem may be related in part to the Whig party's frequent use of an epic-like rhetoric to defend their conservative ideology. Because the Whigs played such an important role in Whitman's conception of the political climate of the mid- to late-1850s, it proves useful to examine their rhetoric at its most coherent (in the late-1830s and 1840s). While Whitman celebrated the unlimited possibilities of an unsettled American continent, the Whigs worried about constancy and tradition. When the Whigs voiced their disapproval of the Mexican War, it was because, as a risky attempt at brazen territorial extension, it threatened the stability of the American Union. A September 1845 article in the American Whig Review entitled "Will There Be War with Mexico?" illustrates the Whigs distrust of expansionist policies: "Wars are fraught with crime, are dangerous to liberty, and necessarily tend to the subversion of those institutions upon which our political and social fabrics rest." 11 If the Whigs feared that the war threatened to subvert the institutions which support "our political and social fabrics," the Democrats saw it as an opportunity to secure "freedom" for the individual, a belief in which rapid and uninhibited expansion was an inevitable component. Major Wilson has labeled this difference as one between the Democrats' interest in a "quantitative expansion" through space, while the Whigs were concerned with a "qualitative development" through time. The Whigs looked for "internal improvements" and saw "external expansion" (such as the War with Mexico) as a threat to this internal stability. ${ }^{12}$ Although Whitman's pacifist instincts ultimately caused him to question the violent results of the Mexican War, he initially supported the war with enthusiasm, as well as nearly every one of James Polk's expansionist policies. ${ }^{13}$

However, Whitman's political involvement certainly was not limited to the Mexican War. When he was writing the original version of "Song of Myself," he was very active (as a journalist, speaker, and occasional canvasser) in the political debate of the late 1840s and early 1850s. ${ }^{14}$ As biographers of Whitman have pointed out, in these decades he heavily supported the Democratic party. ${ }^{15}$ In fact, as early as the 1830s, Whitman held an apprenticeship with The Patriot, a Democratic newspaper which supported the Democratic workers against the Whig 
manufacturers. Later, while Whitman was in Queens County, a Whig paper labeled him as a "well-known locofoco [radical democrat] of the town ... a champion of Democracy" (Erkkila, 14, 20).

Because Whitman's alliances and rivalries initially were divided so clearly along party lines, a brief look at general tenets of the Whig and Democratic parties will be useful. Although such distinctions inevitably are somewhat schematic and neglect conflicts within each party, they do provide a helpful context for Whitman's poetry. So, if the following outline seems to reduce the two parties to a simple binary, it does so in order to demonstrate the conflicting rhetoric of the period. While party politics are never cut and dry, the rhetoric surrounding these politics often are, and it was the Whigs' rhetoric, as much as any specific platform, to which Whitman objected. Whereas the Democrats claimed to be accepting of cultural and moral diversity as long as it supported their notions of personal freedom (in fact, it was a vital aspect of their myth of democratic independence), the Whigs invoked a culturally uniform society that "mut[ed] social conflict" (Howe, 20). In fact, much like Virgil, who justified the contemporary Roman Empire by mythically depicting its history, the Whigs spoke of the ultimate value of the past and, as upholders of conservative morality and stewardship by the educated elite, felt responsible for dictating what a culture should cherish and respect. As one historian of nineteenth-century America explains, an appropriate Whig leader "must not only defend the people's true interests but show the people where those interests lay" (Howe, 27).

In part because they presented themselves as social, political, and ethical guardians, the Whigs' ability to manufacture ideological consensus, as was the case with the epic poets, lay in the efficacy of certain rhetorical ploys. ${ }^{16}$ By looking at how Whig politicians attempted to justify ideological systems (rather than looking at what values they specifically justified), we can see how the Whigs and Virgil use a rhetoric of unification in very similar ways. Both Virgil and members of the Whig party spoke in terms of a unified and harmonious cultural history; they frequently used metaphors and images that appealed to the audience's desire for stability and continuity without providing substantive explanations of their motivations. By speaking in terms of a mythic historical tradition (which they were merely continuing), the Whigs, like Virgil, invoked the sanctity and destiny of the past. By attaching the mythic history to the present situation, the Whig speakers were able to claim they were following precedent; consequently, they were not responsible for the present implications of their ideological policies. For example, by claiming that they wished to preserve the harmony of the American Union (both past and present), the Whigs were able to resist any movements of reform because they strayed away from national tradition. Notice how the author of "Our Country Maryland" in the 
1845 American Whig Review dismisses the Democratic call for greater material equality: "Commend us to the spirit of the Past-the chivalric and thoughtful spirit, that prompted to wise counsel and valorous deedswhen worth was not gauged by the standards of wealth or fashion."17

None of these reform movements threatened the Whigs' reverence for past precedent more than the Women's Rights movement. Never did the conservative Whig politicians more assiduously call upon the harmony of the past and present than in their attempts to halt an increase in women's privileges. Like Virgil's Roman "nationhood," the Whigs' ideas of an organic harmony (one that informed the structure of society) contained a very specific and rigid, if unstated, hierarchy. In the 1848 article "Woman's Rights" in The American Whig Review, the unnamed author justifies the present sexual hierarchy and its attendant privileges by explaining it in terms of the Great Chain of Being. The article argues that since life has its root in the "sphere of nature" and woman was taken from man's side, any attempt to reverse, or alter, this hierarchy would be tampering with the organic harmony of the world: "With such natural and personal difference, the sexes are designated from the start to different spheres of life, and have widely different missions to fulfill in the social system." 18 While this argument is hardly original (and certainly not exclusive to the Whig party), the manner in which the author attempts to justify this assertion does illustrate the Whig tendency to use the myth of an organic harmony as a way of preserving "natural" and hierarchical values.

By claiming that any movement towards sexual equality would disrupt the fragile balance of the natural world, the author argues that women must forfeit their individual aspirations for the preservation of the whole: "This subordination of the single life to the general is of such vast consequence to the entire plan and structure of the moral world, that it must be secured by an invincible guaranty in the constitution of the world itself" (376). Invoking the "constitution" (both the political document and the natural coherence and interdependency of the world) is a favorite Whig rhetorical ploy, connoting a pre-ordained order. In this article, just as the Whigs called for a strong federal government rather than the autonomy of the individual states, the author champions the "subordination" of the "single life" to the "general." Therefore, advocates of Women's Rights are threatening the "entire plan" of the "moral world"- an exceptionally serious burden. Conveniently, it is the subjugated women who must make the sacrifice to preserve the Union; it is they who must accept the adverse consequences of a historical precedent of a fixed sexual hierarchy.

Whitman, on the other hand, strategically places women in the center of the pluralistic universe of "Song of Myself." Whitman's inclusion of women, and his emphasis upon gender equality seems to counter directly the Whigs' conception of gender roles: “A great poem is for 
ages and ages in common and for all degrees and complexions and all departments and sects and for a woman as much as a man and a man as much as a woman." ${ }^{19}$ Unlike the Whigs, who claim historical precedent in their oppression of women, Whitman's democratic ideal confronts traditional sexual roles:

I am the poet of the woman the same as a man,

And I say it is as great to be a woman as to be a man,

And I say there is nothing greater than the mother of men. (26)

Even the balanced phrasing of these lines contributes to the emphasis on equality. Although Whitman often depicts women in traditional spheres (as a mother or domestic recluse), he clearly intends to include women on equivalent terms in his revisionary moral universe. I am not claiming that Whitman does not present troubling images of women (as in his tendency to envision women as vessels that serve little purpose other than to contain and give birth to future generations - the "mother of men"), but his rhetoric of gender equality and his conscious attempt to place women prominently in his new America suggest a very different way to approach the world than does the Whig emphasis on tradition and constancy.

While the debate about the rights of women and sexual privilege was certainly volatile, slavery, as another matter of hierarchy and subjugation, was probably the most divisive ideological and political issue of the 1840s and 1850s. When Congressman David Wilmot suggested that slavery be forbidden in new states, the Union was instantly fractured. The turmoil and disagreement which this issue created threatened the stability of the nation. However, in his famous speech "The Constitution and the Union," delivered on March 7, 1850, the Whigs' premier orator Daniel Webster used images of unity and harmony to emphasize the Union's constancy and durability. Although the Whigs, as a party, were opposed to slavery in the new states, Webster saw the need to compromise. ${ }^{20}$ Because, like most Whig politicians, Webster perceived the unity and harmony of the Union and its central government as one of the nation's most precious ideals, he felt he must take steps to preserve its fragile coherence. In this speech, Webster emphasizes the preservation of what is sacred and the need to rely on national tradition and precedent:

Never did there devolve on any generation of men higher trusts than now devolve upon us, for the preservation of this Constitution and the harmony and peace of all who are designed to live under it. Let us make our generation one of the strongest and brightest links in that golden chain which is destined, I fondly believe, to grapple the people of all the States to this Constitution for ages to come. ${ }^{21}$ 
By claiming to desire the "preservation of the Constitution" and the "harmony and peace of all," Webster tacitly recommends the perpetuation of the status quo. Through the image of links in a destined chain, he promotes what he sees as the natural and systematic unity of conservative American politics. According to Webster, the "preservation" of the Union is inextricably bound to this inherent continuity and harmony. Whereas the Democrats often spoke in terms of the individual's "unalienable rights," the Whigs were more likely to invoke the citizen's "duty" (or, in Webster's case, "higher trusts") to the Union and, by association, the central government (Howe, 16). By speaking of one's duty to uphold the inherent harmony of conservative politics, Webster is able to paint any opposing political theory as unnatural or discordant and anarchical-as breaking the "golden chain" which "grapple[s]" the American people. Inevitably, this "golden chain" extends into the mythic past of American politics; the duty of "our generation" is merely to preserve the existing harmony. In this context, it is not surprising to learn that, whereas Whitman writes his anti-epic in contrast to Virgil's Aeneid, in his famous speech "The Bunker Hill Monument" Webster refers to the Roman epic favorably, linking the positive example of Anchises with the birth of the United States. He quotes Anchises without translation: "Totamque infusa per artus / Mens agitat molem, et magno se corpore miscet." 22

Like Virgil, the Whigs tend to look to the past as a means of maintaining a conservative social order. By sanctifying the past, they can censure any Democratic claim for reform as "a perpetual revolution, cutting off the past from the present." In "The Future Policy of the Whigs," published in the April 1848 American Whig fournal, the author criticizes the Democrats for allowing the multitude "to govern the few by the many," a policy which keeps the individual in fear of the masses: "[The Whigs] regard the government as unchangeable except by a solemn decision of the nation in convention, the [Democrats] treat it as inferior in authority to the public opinion of the day." ${ }^{23}$ Like epic poets, who generally espouse a conservative ideology that is resistant to drastic revision, the Whigs tended to attack any form of radical social change as chaotic and frivolous.

Whitman, by contrast, appropriates the epic voice to confidently dismantle these very stabilities, to disturb the accepted cultural continuity. Whereas the epic poet often relies upon the infallibility of the "high" epic voice in order to mute conflict and unify political and ideological sentiment, "Song of Myself" is filled with images of destruction and revolution that directly challenge the unifying metaphors of the "destined" epic poem, suggesting that "Song of Myself" is a radical reevaluation of conventional epic ideology. In the often-ignored catalogues of American experience (sections 10-23 in the 1881 version of the poem), 
Whitman's epic-like voice resounds with the prophetic self-assuredness that is generally associated with the classical poets. ${ }^{24}$ However, whereas The Aeneid and "The Future Policy of the Whig Party" stress the continuity and unity of their ideological foundations, Whitman constantly emphasizes the breakdown of accepted values through metaphors of disintegration that point to his revaluative agenda:

The butcher-boy puts off his killing-clothes, or sharpens his knife at the stall in the market,

I loiter enjoying his repartee and his shuffle and breakdown.

Blacksmiths with grimed and hairy chests environ the anvil ... there is a great heat in the fire. (20, emphasis added)

What Whitman enjoys, and finds instructive, is the process of the butcher's "breakdown," or disassembly, rather than his finished product. He presents the butcher's action as a perpetual dismantling that is not focused on the completion of the task. Similarly, what becomes valuable in the blacksmith's work is the moment of creation-not the result. Whitman focuses on the "great heat of the fire," which is capable of deformation and reformation. He stresses the potential for change rather than the specific results of such a process. Furthermore, by concentrating on the labor of the working class, Whitman is exalting the common laborer instead of the Whigs' educated elite.

These conjoined images of destruction and creation, disintegration and potentiality, directly inform Whitman's political agenda and its influence on "Song of Myself." Indeed, Democratic political theory was often based on the rhetoric of constant change and restructuring at the hands of the younger generation and lower classes. A lucid example of the Democratic sentiment can be found in the article "Congress, the Presidency, and the Review," in the March 1852 Democratic Review: "Young America is the inheritor of their only principle, to throw aside hereditary servility, old-fogy fears or old-tory predilections, and live by their manhood, by mastering the necessities and wants of the time, and shaping their acts accordingly, utterly regardless of do-nothing precedent." ${ }^{25}$ In this passage, the author stresses the notion of a fluid, and constantly evolving, political system which adapts to "the necessities" of the time, while scorning the ineffectual and stagnant "do-nothing" precedent.

Like the radical Democrats that described themselves as defying "obsolete" models, Whitman yokes traditionally opposed images and impulses, thus challenging the relevance and authority of their definitions. Indeed, his destructive agenda disputes conventional demarcation and sentiment by reconciling the apparently unreconcilable: "Evil propels me, and reform of evil propels me" (28); "One side a balance 
and the antipodal side a balance" (28); "A word of the faith that never balks, / . . Hurrah for positive science!" (28). However, this section of the poem that merges thesis and antithesis concludes with a resounding image of revolt: "Beat the gong of revolt, and stop with fugitives and them that plot and conspire" (29). Furthermore, unlike in the previous lines, there is no reversal or opposition to Whitman's identification with the revolters. By beating the "gong of revolt" and unifying his "heroic" narrator with the rebellious, Whitman is signaling his alliance with the revolutionary and disruptive factions of American society. In this passage, Whitman challenges everything that is "organic," traditional, and customary, preferring instead to stop with "them that plot and conspire."

While Whitman and the Democrats generally felt that the potential for this type of revaluation was the only way to avoid the "do-nothing precedent" and insure a truly representative republic, the Whigs saw such a policy as the failure to heed governmental precedent: "Ultra Democratic doctrine indulges men in a perpetual revolution, cutting off the past from the present" ("The Future Policy of the Whigs," 330). In the Whigs' lexicon there was scarcely a more loathsome word than "revolution," which suggested an irresponsible pandering to fickle public sentiment.

Seemingly attacking directly the Whigs' suspicion of rapid social change, Whitman's poem is based on the value of revolution. Once again in the same catalogue, Whitman paints the rebelling masses in favorable terms, but it is important to note the sense of productive order (in this case the harvest) that follows his examples of revolution:

The meeting of enemies, the sudden oath, the blows and fall,

The excited crowd-the policeman with his star quickly working his passage to the centre of the crowd;

What living and buried speech is always vibrating here ... . what howls restrained by decorum,

The big doors of the country-barn stand open and ready,

The dried grass of the harvest-time loads the slow-drawn wagon . . . . (18)

Rather than conservative moral instruction, the "living and buried speech" becomes one of the vital aspects of American society; the restrained "howls" signify Whitman's belief that unvoiced sentiment lies just beneath public propriety. The nation's (and specifically Whitman's) task is to strip away "decorum," which is without a substantive foundation but remains essentially unquestioned. However, when the "excited crowd" (or as the Whigs might say, "unruly mob") ignores the policeman and "his star," they are defying more than mere "decorum;" they are revolting against conventional roles and traditional sites of author- 
ity. Seen in a larger political scope, this passage directly opposes the Whig's call for conservative morality and the subordination of local rights to the "superior" federal plan.

Whitman suggests that the key to a revolt against such "decorum" is the liberation of speech. This notion fits with Whitman's reverence for democratic ideals; indeed, unrestrained expression through speech, especially slang, is an essential facet of his idea of American individualism. The image of the harvest, ready but not yet begun, that directly follows his "excited crowd" signals the possibility of substantive change. In this instance, Whitman is clearly beginning another image when he speaks of the harvest time, but it is precisely how he chooses to juxtapose these apparently incongruous images that tells us so much about his revolutionary stance.

John McWilliams has pointed out that epic poetry often (if not inevitably) serves to reaffirm the social order and cultural values of the time. What seems to be a liberating and unifying document of cultural celebration, according to McWilliams, actually glosses over the diversity within a society: “Man's greatest medium for changing society's attitude, epic poetry, has repeatedly betrayed its promise. Instead of serving mankind, the epic has reclothed old barbarism in a new aristocratic dress" (56). Perhaps for this reason, McWilliams refuses to place Whitman's poem in the context of the American epic. Although he is perhaps overly critical of the epic genre, ignoring the formalized martial tradition of the poetry, McWilliams is correct in referring to Whitman's "anti-traditionalist" agenda. However, what he does not point out is that in "Song of Myself" Whitman is using the convention of the epic narrator for the very reason of its conservative, static, and distant nature. By juxtaposing seemingly incongruous images while employing the artifice of an unifying epic narrator, Whitman is able to manipulate the convention and partially remove the cloak of ideological infallibility from epic poetry.

In fact, in "Song of Myself," the narrator's resounding voice calls into question the official, monolithic nature of the epic by creating an indeterminate chaos, where traditional definitions and structures have little or no meaning. In the seemingly endless epic-like catalogues of the poem, Whitman hints at his ideological revaluation of American society. Unlike Whig ideology or Virgilian genealogy, there is certainly no Great Chain of Being or catalogue of heroic descendants in a dynastic succession in Whitman's revisionist poem; every person, every event is given equal attention, and nothing is excessively glorified or scorned. Aristocratic genealogy gives way to democratic, random lists. By juxtaposing conventionally disparate images and presenting them in equally weighted terms, Whitman presents what he understands as a revolutionary pluralistic ideal. In fact, every time a figure of established 
traditional valuation is introduced, the portrait is undermined with an immediate description of a person on the losing end of strict societal determinations: "The bride unrumples her white dress . . . / The opium eater reclines with rigid head" (22). The "pure" bride is not kept cloistered in "Song of Myself;" rather, she is positioned adjacent to the semi-conscious drug user. Furthermore, the fact that she is "unrumpling" her dress questions whether such notions of purity and morality have significance in Whitman's cosmology. Whitman seems to be questioning fundamental aspects of cultural decorum, asking why and by whom these ideas of propriety have been created.

By bringing his poem into dialogue with the epic tradition through these epic-like catalogues, Whitman can simultaneously destabilize some of the ideological certainty of the epics and invent his own revaluative agenda that reexamines the most firmly established cultural definitions: "Patriarchs sit at supper with sons and grandsons and great grandsons around them, / In walls of abode [sic: adobie], in canvass tents, rest hunters and trappers after their day's sport" (23). In this passage Whitman inverts the word order of the second line in order to create a metaphorical melding of the patriarchs and the hunters. Upon an initial reading, the phrase "In walls of abode, in canvass tents" seems to be referring to the patriarch's environment, when in fact at least half of the phrase describes that of the hunters. Whitman not only constructs a sense of equality through the juxtaposition and poetic enjambment of aristocrats and lower class people, he also creates a referential instability, where traditional definitions and boundaries are disintegrating, even on the verbal level. In her biography of Whitman, Bettina Knapp isolates his revaluative agenda: "He was forever searching for ways to break down society's masks, its unshakable beliefs, its rigid thought processes, most frequently used by groups and individuals as defense mechanisms to protect them from the 'dangers' awaiting those who open their minds to untrodden paths." 26 As Knapp hints, hierarchies are created and maintained, in part, by "unshakable beliefs" which justify such an ordering and which often forbid any questioning of the existing order. Knapp uses these terms to describe Whitman's "shock techniques" that she believes allow him the "freedom and abandon he needed to reap the joys of earth" (87). This analysis seems to be too personal, ignoring Whitman's social and political agenda. Nonetheless, although she does not discuss the political milieu of Whitman's poem, Knapp implicitly identifies the Whigs' desire to maintain society's decorum, the "masks" that Whitman so ardently seeks to remove.

For Whitman, one of the surest ways to disrupt this cultural decorum in his poem is the constant variation of tone and diction. At times he is elegant and refined in his speech: "My own voice, orotund sweeping and final" (46). In these poetical moments, Whitman's narrator takes on a high and commanding tone that closely mimics conventional epic 
narrators. Then, often in the very next line, he becomes more sensual and imagistic - a man on the streets - mentioning that "washes and razors [are] for foofoos" (28). Through this use of slang and depiction of the everyday, Whitman calls attention to, and distances himself from, the artifice of epic poetry. ${ }^{27}$ Indeed, Robert Scholnick points to the role of slang ("artlessness") in Whitman's revolt against the epic tradition: "Just as the 'rude' manners of the persona enable him to break with all social conventions in favor of an ostensibly original and authentic way of relating to others, so he adopts simplicity and artlessness to break with the conventions of his poetic predecessors." 28 Although Scholnick is dealing here with Whitman's revolution in a purely aesthetic sense, he does correctly identify Whitman's separation from his "poetic predecessors." By initially implicating his work with the legacy of epic poetry through his "orotund" voice, Whitman forces a clash between the rigidity and formality of epic poetry and what he believes to be the commonality and spontaneity of "Song of Myself." Scholnick limits this separation to an artist's "anxiety of influence," but Whitman's political involvement seems to suggest that the division between "Song of Myself" and the epic genre represents not only an artistic revaluation but a radical Democratic statement as well.

Whitman's oscillating tone may appear to be his attempt to retain poetic grandeur while simultaneously writing about "what is commonest and cheapest and nearest and easiest" (21), but actually the alternating of narrative voice points to the core of Whitman's destructive agenda. By depicting, and calling attention to, this stratification of language and subject matter, Whitman creates a symbolically democratic poem, where the awe-inspiring mingles with the wearisome; he believes that he is representing the myth of American diversity, multiplicity, and independence. In "Song of Myself," epic distance is not eliminated; the "distant" epic voice becomes intertwined with the basest, and most immediate, linguistic forms. As McWilliams states, "Whitman mixes levels of language in order brashly to assure us that Truth exists in every rank and order" (225). In fact, without Whitman's manipulation of the epic voice - without the sense of epic distance and sublimity through much of the poem-his "rude manners" and plebeian language would not have the revolutionary effect that they do. Whitman must first superficially construct an epic formality in order to reveal its deficiency.

While the Whigs promoted the continuity between the present and past, the Democrats were more inclined to question the validity of what they would call a coerced harmony. Indeed, the Democratic rhetoric of the time is filled with diatribes that cherish the value of the future because of its break from, and abandonment of, the past. In an article in the March 1852 Democratic Review, entitled "Congress, the Presidency and the Review," the author scorns the idea of relying on "connection" to past politicians (in this case, Jacksonian Democrats): 
Young America is not the offspring of old fogydom. Being wise in our generation, and being determined not to be burthened with more fathers than there is any need for, we declare that the young democracy, either in its principles or its actions, has no connection either in blood, policy, consanguinity, or look, with those antiquated, stiff-cravated personages, who have hitherto regarded themselves as the owners of the Democratic party. (203)

The writer stresses the obsolescence of past political "principals" or "actions." In this quotation by a radical faction of the Democratic party, we can see the "Young Americans" unhesitatingly optimistic view of the future. By denying any relation whatsoever with their political predecessors, these "young" democrats (like the young Jacksonian democrats before them, who have since evolved into "antiquated, stiff-cravated personages") have spurned past ideology for an undetermined future that is not governed by a "do-nothing" precedent.

Whitman similarly desires to wrench apart the continuity between past ideological doctrine and present political practice. For Whitman, as for most Democrats of the time, a society without rigid social constructs and definitions is more apt to accommodate change and reevaluation. ${ }^{29}$ Throughout "Song of Myself," Whitman's narrator aligns himself with the oppressed and suffering people in America. Although he thoroughly depicts the privileged and aristocratic in the poem, he always identifies with those who are under attack:

The hounded slave that flags in the race and leans by the fence, blowing and covered with sweat,

The twinges that sting like needles his legs and neck,

The murderous buckshot and the bullets,

All these I feel or am.

Agonies are one of my changes of garments;

I do not ask the wounded person how he feels . . . . I myself become the wounded person .... (39)

Whitman describes this pursuit in haunting detail and identifies with the wounded slave. Although he has just claimed to "understand the large hearts of heroes" (38), Whitman ultimately empathizes instead with the injured, the dying, and the defeated. Rather than objectively reporting the slave's plight, he becomes the slave: "I am the man .... I suffered .... I was there" (39). The rhetoric of epic poems can manipulate the excitement of battle to downplay the underlying controversial, and questionable, ideological import of the conflict. Whitman uses the suffering of the losers to undermine the foundation of such a claim.

Despite his apparent reliance on a Jacksonian exaltation of the "common man," Whitman does not believe he is displacing one ideology with a new ideology which will become generative of ossified cultural truths. Rather, he wishes to suspend certainty and absolute ideological 
doctrine and "loafe" in the resulting multiplicity. If we examine closely Whitman's statement in the 1855 preface that the expression of his poetry is "to be indirect and not direct or descriptive or epic" (iv), we can discern how it relates to his revolutionary and destructive agenda within "Song of Myself"-how he rebels against the very essence of Whig rhetoric. In many ways, this phrase provides a schematic outline of Whitman's agenda in "Song of Myself." The poem is to be "not direct or descriptive" - the message is not going to be excessively overt, and the poem is not going to fit snugly into predefined categories or national dogma. To do so would align his poem with the Whig rhetorical strategies he confronts. Instead, Whitman wishes that the diaphanous meaning of "Song of Myself" be revealed in multiple layers, contradictions, and conundrums that resist a monolithic and unified interpretation. Poetry, for Whitman, should remain "untranslatable" and represent the "indirect" potentiality of the unknown rather than "descriptive" doctrinal statements: "If [these thoughts] are not the riddle and the untying of the riddle they are nothing" (24). Indeed, in 1855 Whitman views ideological and political uncertainty as virtually synonymous with potentiality - the "chaos" of the future is a positive force.

In this way, for Whitman the lack of ideological certainty is not an unfortunate and terrifying result of his revolution; it becomes the guiding principle of his philosophy. In perhaps the crowning statement of "Song of Myself," he declares,

\section{Do I contradict myself?}

Very well then . . . . I contradict myself;

I am large . . . . I contain multitudes. (55)

Rather than creating meaning through the buttressing of conservative myth and historical hierarchy (as do Virgil and the Whig politicians), Whitman's rhetoric finds purpose in the destruction of absolute meaning and ideological foundation.

Ironically, even though Whitman combats these unifying tendencies and exposes their rhetorical underpinnings, he appears to be blind to his own ideological framework and rhetorical ploys. Just as Virgil justifies the colonization of the Roman Empire, Whitman sees Manifest Destiny as the ideal manner to insure the American sense of individuality. In order to maintain the myth of unfettered individuality, there must be a vast expanse of potential territory to conquer or to escape to. That is to say, a community based on unrestricted individuality functions much more smoothly if there is sufficient area (such as the nineteenthcentury Western frontier) to sustain a profusion of individual pursuits. 
Virgil uses the myth of a destined imperialism to explain a cultural heritage. Whitman, in similar fashion, sees the unsettled continent as a sign of future freedom and potentiality. So while Whitman may identify with the wounded slave in a manner which exposes the epic poem's reliance on martial conquest and heroic battles, he also exalts the ship fight of John Paul Jones with the patriotic fervor of a zealous nationalist. Similarly, when he describes the Mexican War in his poem, Whitman always sides with the "heroic" American soldiers. In short, when it comes to the myth of Manifest Destiny, Whitman becomes staunchly nationalistic. Although Whitman's and Virgil's explanations of colonialism serve different political ends, both writers are trapped in their own ideological and nationalist assumptions which buttress their political and poetical beliefs.

Indeed, to our current sensibilities, Whitman's poem seems imbued with prescriptive ideological commentary. From the all-encompassing and almost didactic declaration that begins "Song of Myself" ("I celebrate myself, / And what I assume you shall assume") to the concluding lines which emphasize the enduring legacy of Whitman's message ("Missing me one place search another, / I stop some where waiting for you"), Whitman presents an almost imperialist ethos, one which devotedly, and at times unquestioningly, exalts the "Common Man." Certainly such a perspective is inextricably bound to the cultural dynamics of a firmly established mid-nineteenth century liberal ideology. However, as the lack of any punctuation at the conclusion of the poem suggests, Whitman seeks to underscore what he believes to be the unbridled and open-ended nature of his work. Certainly, we have seen that such "revolutionary" ideas are not somehow above, or removed from, ideological doctrine; nor does such an ideological framework preclude a work from being truly innovative or rebellious. Nonetheless, for Whitman ideology and cultural conservatism are insidiously linked. As Whitman confidently rejects "the old myths" of the classical epics, he unconsciously creates a new myth: a poem free of ideology.

Not surprisingly, Whitman's belief that he lacks a rigid ideological foundation seems fitting with the Democratic ideology of the pre-Civil War era. As Thomas Hietala discusses in his book on Manifest Destiny, the Democrats fervently defended laissez-faire economic practices and territorial expansion, not solely because of an overly ambitious confidence in the American future; rather, they perceived these tenets as prerequisites for "a society based upon individual acquisitiveness, geographical and social mobility, and a fluid class structure." ${ }^{30}$ Ironically, the Democrats cherished this doctrine of rapid expansion, which proved to be one of the most tyrannical legacies of American history, because it helped to insure the liberation, decentralization, and freedom of American society, a future they saw as endangered by Whig conservatism. 
In the November 1839 volume of The Democratic Review, John O'Sullivan, the founder of The Review and a staunch supporter of Manifest Destiny, states in his article "The Great Nation of Futurity" that "our national birth was the beginning of a new history, the formation and progress of an untried political system, which separates us from the past and connects us with the future only. We may confidently assume that our country is destined to be the great nation of futurity" [emphasis added]. ${ }^{31}$ Like O'Sullivan's "nation of futurity," Whitman's vision of the future is filled with a democratic optimism that leaves the past behind in order to invent the future. Indeed, in "Song of Myself" Whitman's celebration of an unregulated multiplicity seems intimately related to the Democratic criticism of the Whigs' reliance on the past and a traditional centralized government. Compare O'Sullivan's comment, "We have no interest in the scenes of antiquity, only as lessons of avoidance of nearly all their examples" (427) with "Song of Myself": "I do not know what is untried and afterward, / But I know it is sure and alive and sufficient" (49) and,

Soft doctrine as steady help as stable doctrine,

Thoughts and deeds of the present our rouse and early start.

This minute that comes to me over the past decillions,

There is no better than it and now. (28)

Because of an unabashed confidence in the present and future of American society, both O'Sullivan and Whitman seem to cherish their repudiation of historical precedent-valuing the "untried" over the firmly established. Furthermore, both writers use a rhetoric that suggests they are free from rigid ideological doctrine, when in fact they are deeply fixed in their own political and ideological sentiment. Certainly, this type of unconscious ideological sentiment-by virtue of its veiled existence-is among the most powerful of cultural determinants, influencing the manner in which a culture views itself; it is also one of the interpretive keys to Whitman's anti-epic, displaying his reliance on the Democratic trust in Manifest Destiny.

Although, as we have seen, Whitman relies heavily upon Democratic political doctrine, ultimately he does not wish to be confined by a prescriptive ideology-Democratic or Whig. As Betsy Erkkila has pointed out, in the late 1840 s and early 1850 s, Whitman became increasingly disgruntled with the fixity of the Democratic party, and party politics in general (47-58). ${ }^{32}$ Certainly, by 1855 Whitman is not interested in simply writing a poem exalting the American Democratic party; rather, he envisions a metaphorical "union" that is not structured around rigid historical and nationalistic determinants. ${ }^{33}$ Whitman's metaphorical union celebrates the multiplicity that often exists within, but is not ex- 
clusive to, the United States. In fact, he treasures its very lack of political and cultural homogeneity: "I am . . . / One of the great nation, the nation of many nations - the smallest the same and the largest the same, / . . . Not merely of the New World but of Africa Europe or Asia" (2324). Although the inclusiveness of these lines can be attributed in part to Whitman's all-encompassing "I," they seem to illustrate Whitman's belief that "Song of Myself" is not solely a poem about American Democratic ideology. It is interesting to note that these lines are eliminated in later editions when Whitman seeks to create a more traditional and national epic; by the time the Civil War ended, Africa, Europe, and Asia no longer fit into his poem of the New World.

Indeed, despite Whitman's obvious political and ideological bent, he firmly believes he is avoiding prescriptive doctrine. Even Democratic respect for plebeian labor and the working classes is too uncompromising for Whitman's revisionary cosmology. In an 1847 editorial, Whitman illustrates his repudiation of any anchored political affiliation and his exaltation of the "liberty" of the American individual:

One of the favorite doctrines of leading Whigs teaches the intricacies and profundity of the science of government .... We have Democrats ... [who] assent to the same views ... Really, however, the principles that lie at the root of true government, are not hard of comprehension. The error lies in the desire after management, the great curse of our Legislation: every thing is to be regulated and made straight by force of statute. And all this while, evils are accumulating, in very consequence of excessive management. The true office of government, is simply to preserve the rights of each citizen from spoliation: when it attempts to go beyond this, it is intrusive and does more harm than good. ${ }^{34}$

Rather than defining what the future holds, Whitman would "loafe" in its very ineffability. To elucidate this idea, he chooses the metaphor of the open road: "I tread day and night such roads" (38). "Not I, not any one else can travel that road for you" (52). Although he focuses on the road, it is a road without a destination. The road is not a means to an end; it is the end in itself - the "perpetual journey." Although (as this endless road illustrates) Whitman consciously challenges the most deeply ingrained conservative ideological and political beliefs of his time, it would be wise to remember his own ideological investment. To refer to a cliché that invokes the era of Virgil's epic that Whitman so adamantly rejects, "All roads lead to Rome." Roads are routinely designed, constructed, and maintained by the prevailing empire in a manner which overtly benefits this empire. In this light, Whitman's "open road" (his indeterminate poem) can be seen, in part, as a visible sign of the American democratic empire.

\section{The University of Florida}




\section{NOTES}

I would like to thank Robin Grey; without her countless readings of drafts and challenging comments this essay would not exist. Thanks also to George Hutchinson, whose suggestions and criticism helped with the genesis of this project.

1 Walt Whitman, An American Primer, ed. Horace Traubel (Boston: Small, Maynard, and Co., 1904), 32-33.

2 Cited in John McWilliams, The American Epic: Transforming a Genre, 1770-1860 (Cambridge: Cambridge University Press, 1989), 222.

3 In the 1850 s, Whitman's connections with the epic tradition would have been even more obvious than today. During this time, there was a great longing for the first great American epic poem. Many critics in the nineteenth century felt that American letters could never fully cut ties with the old world until a "successful" epic was written. As a consequence, there were numerous American works that were compared with the European epic poems, such as Timothy Dwight's "The Conquest of Canaan," Mason Locke Weems' "The Life of Washington," and Joel Barlow's "Columbiad." As "Song of Myself" gained popularity in the mid-nineteenth century, it was immediately discussed in relation to past European and American epics. See McWilliams, chapters 1 and 7.

4 Suzanne Wofford, The Choice of Achilles: The Ideology of Figure in the Epic (Stanford: Stanford University Press, 1992), 16.

5 For example, in 1951 Ferner Nuhn claimed that "Leaves of Grass belongs in the category of bardic or epic literature. It represents an Epos of modern democratic culture, expressed in an appropriate aesthetic form. The particular culture which it presents is that of North America, but there runs through it a core of universal and permanent truth" ("Leaves of Grass Viewed as an Epic," Arizona Quarterly 7 [1951], 326.) Andrew Hudgins sees Leaves as an extension of the traditional epic with Whitman consciously trying to "connect" his work with the genre ("Leaves of Grass from the Perspective of Modern Epic Practice," Midwest Quarterly 23 [1982], 380-390). John McWilliams states that "Song of Myself" is a mix between a heroic and mock-heroic poem, but believes the poem is a "defiant rejection" of the epic tradition $(224,226)$. Charles Metzger writes that Whitman is revising the epic tradition by "concentrating heavily upon the wounded, the dead, the defeated" ("Walt Whitman's Philosophical Epic," Walt Whitman Review 15 [1969], 91-96). Roy Harvey Pearce discusses the structure of "Song of Myself" in the context of the epic genre: "If we only look at 'Song of Myself' as an exemplar of a further stage in the development of an American epic, we may see how it was necessary for the success of the poem that it be in no way externally or generically structured. In Whitman's conception, this new kind of poem was more a process than a form. ... The new heroic poem, the specifically American Epic, is one of ordering, not of order; of creation, not confirmation; of revealing, not memorializing" (The Continuity of American Poetry [Middletown, CT: Wesleyan University Press, 1987], 73, 83). George Trail states that "Song of Myself" invokes the epic tradition in order to "provide a standard ground from which to deviate and upon which to embroider" ("Whitman's Spear of Summer Grass: Epic Invocations in 'Song of Myself," Walt Whitman Review 23 [September 1977], 120-125). Jeffrey Walker claims that "Whitman's position is not that of the ancient epic poet, who at least in theory could constitute himself as the mouthpiece of the culture to which and for which he spoke. Nor, for that matter, is Whitman's position exactly that of Northrop Frye's 'contrast epic' poet, who could excoriate (or view with ironic contempt) the 
sins of his society from an ethical perspective already recognized by that society as authoritative. The ethical perspectives to and for which Whitman's bard proposed to speak are in large measure antagonistic; the ethical center he proclaims is not, in fact, the center for the culture that surrounds him" (Bardic Ethos and the American Epic Poet: Whitman, Pound, Crane, Williams, Olson [Baton Rouge: Louisiana State University Press, 1989], 20).

6 James E. Miller, Jr., The American Quest for a Supreme Fiction (Chicago: University of Chicago Press, 1979), 33. See also Miller's Leaves of Grass: America's Lyric-Epic of Self and Democracy (New York: Twayne Publishers, 1992); Song of Myself: Origin, Growth, Meaning (New York: Dodd, Mead \& Company, 1964); "Whitman's Leaves and the American 'Lyric-Epic'," Poems in Their Place, ed. Neil Fraistat (Chapel Hill: University of North Carolina Press, 1986), 287-307.

7 For a discussion of this concept, see Suzanne Wofford's introduction to The Choice of Achilles. There, Wofford discusses the ways in which ideology functions in Renaissance epic poetry. For examples of Whitman's attitude towards the ancient epics, see John McWilliams's chapter, "An Epic of Democracy?," in The American Epic.

8 I will be citing by line number Robert Fitzgerald's translation of The Aeneid (New York: Vintage Classics, 1990).

9 For the purposes of this essay, I am modifying Mikhail Bakhtin's notion of "epic distance." See Bakhtin's chapter "Epic and Novel" in The Dialogic Imagination (ed. Michael Holquist [Austin: University of Texas Press, 1981]). For Bakhtin, epic distance connotes an absolute temporal distance between the reader (and contemporary history) and the "epic world," in which the heroic past is a world of "bests" and "firsts." This distance is absolute and not transgressible and is only bridged by national tradition. Therefore, this distance creates, in epic, a finished product in which "there is no place ... for any openendedness, indecision, indeterminacy" (Bakhtin, 13-16). I am using this term in part to point to both the temporal and hierarchical remoteness that allows an epic poem to promote an ideological system without allowing the dissection and examination of the internal assumptions and presuppositions of that ideology.

10 Sacvan Bercovitch, "The Problem of Ideology in American Literary History," Critical Inquiry 12 (1986), 636.

11 Anonymous, "Will There Be War With Mexico?" American Whig Review (September 1845), 221-229.

12 Daniel Walker Howe, The Political Culture of the American Whigs (Chicago: University of Chicago Press, 1979), 21. Also see Major L. Wilson, Space, Time, and Freedom: the Quest for Nationality and the Irrepressible Conflict (Westport, CT: Greenwood Press, 1974).

13 Betsy Erkkila, Whitman the Political Poet (New York: Oxford University Press, 1985), 39-40.

14 See Erkkila, chapters 1 and 2. Also see Cleveland Rogers and John Black, eds., The Gathering of the Forces (New York: G. P. Putnam's Sons, 1920), a collection of Whitman's political essays and editorials. In these writings, Whitman consistently voices his support for the "true" Democrats and his disapproval of the Whigs's "doctrine of the science of government” (1:53).

15 See Richard Chase, Walt Whitman Reconsidered (New York: William Sloane Associates, 1955), chapters 2 and 3; Erkkila, chapters 3-5; and Bettina Knapp, Walt Whitman (New York: Continuum Press, 1993), chapter 1. 
16 Namely, relying on the past models of a mythic and "destined" history and speaking in terms of an organic social harmony, both of which depict implicit cultural hierarchies as foreordained, inevitable, universal, and/or natural.

17 Anonymous, "Our Country, Maryland," American Whig Review (March 1845), 277.

18 Anonymous, "Woman's Rights," American Whig Review (October 1848), 373.

19 Walt Whitman, Leaves of Grass (Brooklyn, New York: Fowler and Wells, 1855), 22.

20 See the introduction to Webster's speech "The Constitution and the Union, March 7,1850 " in the second volume of Webster's papers, cited in note 21 . In this introduction, Charles Wiltse outlines the Whig resistance to Webster's compromise. Several Whigs believed that Webster had "sold out to the 'slave power' for the presidency" (513).

21 Daniel Webster, "The Constitution and the Union, March 7, 1850" The Papers of Daniel Webster, Speeches and Formal Writings, ed. Charles Wiltse (Hanover, England: University Press of England, 1988), 2:550.

22 Cited in McWilliams, 35.

23 Anonymous, "The Future Policy of the Whigs," American Whig Review (April 1848), 330.

24 The section numbers were added in the 1867 edition. "Song of Myself," of course, was untitled in 1855. These numbers, as well as other revisions, signal Whitman's evolution towards a more traditional poem.

25 Anonymous, "Congress, the Presidency, and the Review," Democratic Review (March 1852), 205.

26 Knapp, 87.

27 In fact, Whitman wrote an article titled "Slang in America" in which he stresses the importance of slang to "New World" poetry. By dismissing the "feudal institutes" of traditional poetic language, slang is "an attempt of common humanity to escape from bald literalism, and express itself illimitably" (Floyd Stovall, ed., Prose Works 1892 [New York: New York University Press, 1963], 2:573).

28 Robert Scholnick, “The Original Eye': Whitman, Schelling and the Return to Origins," Walt Whitman Quarterly Review 11 (Spring 1994), 189.

29 In the January 1853 Democratic Review, the unnamed author of the article "What is Democracy?" writes, "Democracy embodies . . . great principles, among which the most important is that of Equality, with which Liberty is only another name for Aristocracy" (4). Equality, at least in a theoretical sense, implies a greater liberty in personal definition and social construction. For Whitman, democratic ideology protects his notion of radical individualism. He states, "Democracy has its foundations in the very broadest notion of good to our fellow creatures and to our countrymen. It is based on the doctrine of equality in political rights and privileges; it overlooks the distinctions of rank and wealth; it comprehends in its protection all classes and conditions of society, nor allows that the refined and rich shall receive more consideration in its decrees than the poor and lowly born" (cited in Erkkila, 19).

30 Thomas Hietala, Manifest Design (Ithaca, NY: Cornell University Press, 1985), 256. 
31 John O'Sullivan, "The Great Nation of Futurity," Democratic Review (November 1839), 426.

32 See chapter 3, "The Poet of Slaves and the Masters of Slaves," in Erkkila.

33 I am making a distinction here between American Democratic sentiment (which involves patriotic fervor and a specific national identity and pride) and Whitman's democratic ideal (which is founded on the very lack of a definite cultural ideology).

34 The Gathering of the Forces, 1:53-54. 